\title{
Proceeding
}

9th INSHS International Christmas Sport Scientific Conference, 4-6 December 2014. International Network of Sport and Health

Science. Szombathely, Hungary

\section{Analysis of teamwork in officiating in basketball}

\author{
PAVEL SMID \\ Department of Physical Education and Sport, Faculty of Education, University of Hradec, Kralove, Czech Republic
}

\begin{abstract}
Smid, P. (2015). Analysis of teamwork in officiating in basketball. J. Hum. Sport Exerc., 9(Proc1), pp.S330S339. The aim of this paper is to characterise the role, activity and participation of the referees in games with a focus to basketball games. The author generally discusses these issues analysing changes in referees teamwork during the last three years, He presents referees' individual positions on the basketball court (lead, centre, trail), places of their competences, duties and responsibilities. The method of study was direct observation of 45 basketball games during seasons 2012-2014 in mens basketball of the Mattoni National Basketball League in the Czech Republic. The author compares the basic three positions according to the criteria of the area on the basketball court, referees'position and time in the game in relation to the players' personal fouls. Results of the research show significant changes in the participating basketball referees during the game, indicating the most common problems in referees' teamwork and suggestions on how to improve this work. Key words: BASKETBALL; REFEREE; TEAMWORK; FOULS.
\end{abstract}

\footnotetext{
Corresponding author. University of Hradec Kralove, Rokitanskeho 62, Hradec Kralove 3, 500 03, Czech Republic E-mail: pavel.smid@uhk.cz 9th INSHS International Christmas Sport Scientific Conference, 4-6 December 2014. International Network of Sport and Health Science. Szombathely, Hungary.

JOURNAL OF HUMAN SPORT \& EXERCISE ISSN 1988-5202

(c) Faculty of Education. University of Alicante doi:10.14198/jhse.2015.10.Proc1.22
} 


\section{INTRODUCTION}

Basketball was invented in 1891 as a complementary physical activity of students in the winter season at Springfield College in the USA and its author is considered to be an educationalist - PE teacher James Naismith (Dobrý \& Velenský, 1980). The factors which still cause the interest in basketball is its dynamics, originality and surprising solutions of the game situations, surroundings, maturity of its spectators and many others. But the most important factor determining the level of the progress of the game is, according to Trnovsky (1992), considered to be the human factor. In accordance with the invention of the game was the need for its control. Svoboda and Vaněk (1986) report that people have always sought someone neutral to settle disputes. Since basketball is a contact sports game, where positive or negative emotions, the degree of knowledge of the rules and acceptance of decisions by all the participants always play their role, it cannot be expected that rivals with opposing aims would make an agreement. In relation to these criteria, the referees are necessary elements of the game in order to apply the theoretical rules of the game in practice. At the time of its invention and assessment of the 13 basic rules, basketball was perceived as a non-contact game and therefore one referee was enough to control the game (Pumr et al., 1987). With the gradual increase in the speed of the game and the growth of physical contacts, the control of the game was established in pair of officials in 1936 - a referee (refereed personal fouls at players with or without the ball) I an umpire (oversaw the game only), and over the years the officials have been divided into a front and a back referee according to their position on the court and the mechanics of deciding. Their subsequent rights, responsibilities and authorities for decision-making resulted from that (Robinson, 2000).

With the further development of the game, applications and introducing of new rules (e.g. shortening of the time violations from 10 to 8 seconds for the passing from the defensive to the offensive half of the court and from 30 to 24 seconds for finishing of the offensive phase of the game), with the development of power and speed abilities of players, the International Basketball Federation (hereafter FIBA) decided that the highest national competitions have to be controlled by three officials. The Czech Republic accepted this decision in the 2005/2006 season of the highest male competition Mattoni National Basketball League (hereafter MNBL), which was followed by the necessity of the development of new mechanics of the officials. By mechanics we understand the way the officials move and their mutual rotation in relationship to the individual interventions to the game or to the movement path of the ball on the court (Šmíd, 2000). The aim of introducing a third referee was a better coverage of the board and thereby an improvement and refinement of individual decisions in the game. The officials are currently designated as the lead (hereafter $\mathrm{L}$ ), the center (hereafter $\mathrm{C}$ ) and the trail (hereafter T). The new mechanics established their new authorities, locomotion and rotation on the court. Brazauskas (2008) and Hruša (2007) consider the coordination of the work of the group of the three officials to be one of the basic conditions for a successful control of the game. Slepička (1982) describes the cooperation as a complex social phenomenon, which can be examined from the perspective of multiple science disciplines, while he considers it essential especially for collective games. The key point for the quality of decision-making according to Šmíd (2000) is the level of assessment of player's personal mistakes. 


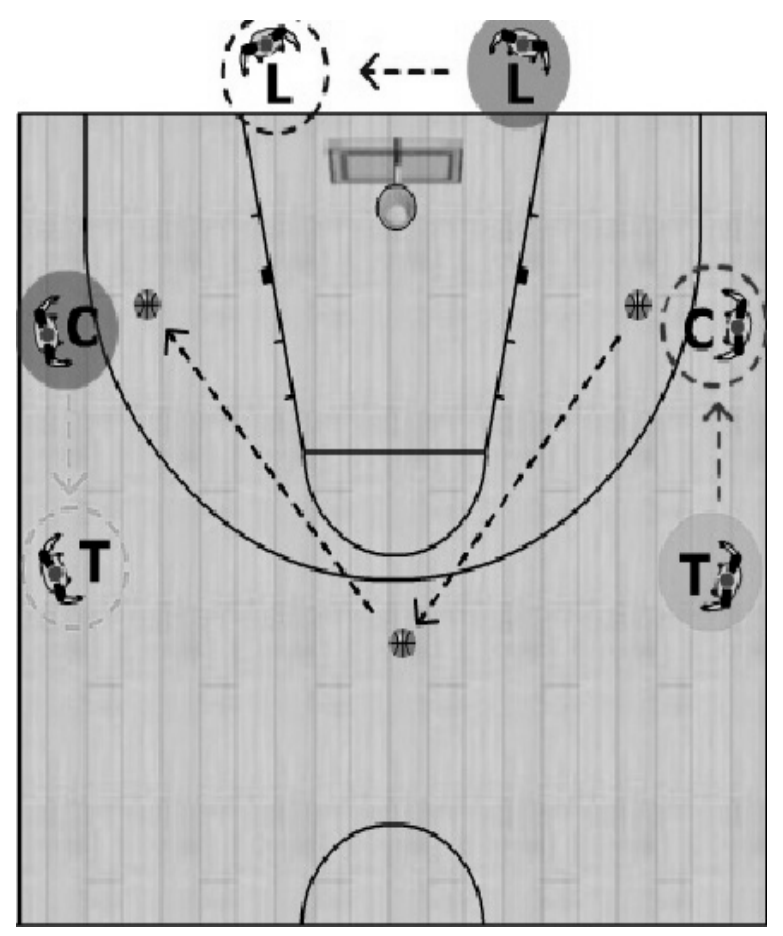

Figure 1. Basic functions and positions of officials on the court and changes of their positions in relation to the movement of the ball

$\mathrm{L}$ - stands along the baseline of the court on the side where the ball is located and together with $\mathrm{T}$ he covers so-called strong side and moves in the direction of the arrow on the figure 1.

T - is on the level with the coaching box bench on the strong side of the court and if necessary he moves to the end line and changes his position to $C$ position

$\mathrm{C}$ - stands on the opposite side than L, T and the ball and he covers so called weak side and if necessary he changes his position in the direction of the arrow to T position and is responsible for the shooting at the basket

The officials must work on their practical knowledge and physical condition constantly during their whole career, which is confirmed by Janáč (1993), Priperkov (2006), Richardson (2007), Šafařik and Stibitz (1978) in their papers. To be an excellent official, one always has to improve and educate himself in his field and to be a strong personality. Making a good decision covers good cooperation of all officials, physical fitness, ability to express, anticipation, quick and accurate decisions, impartiality, act accordingly, quality signalling and others.

The principles of decision making were divided by Vyklický (2008) into 10 parts:

1. Signalling. To communicate with his colleagues, assistant referees at the table, coaches, players, spectators and media, the official is allowed to use the official FIBA signalling only. The intention of this is for each signalling to be confident, precise and clear. 
2. Behaviour and manners. The first impression is often permanent. Precision, appearance, behaviour before, during and after the game are important factors that affect the evaluation of the official in the eyes of people involved.

3. Unity. The officials do not act as individuals, they always form a team. Identical clean and ironed official jersey and trousers and clean shoes are required. Before, during and after the game the official still looks professionally and busy.

4. Physical fitness. It is necessary to follow weekly physical training planes. Every official keeps optimal level of physical fitness, which allows him to manage control of the game and physical tests during a year.

5. Mental preparation. The key factors for good supervision of the game are concentration, self-confidence, calmness and composure. It is necessary to concentrate on the game several hours before the game itself. 6. Pre-game meeting. An essential part of the pre-game preparation is a pre-game preparation with a colleague / colleagues. Discussion of problematic moments while supervising the game, creating a common team strategy of the officials.

7. Post-game feedback. An evaluation of one's own performance and of the performance of the team of the officials. Learning from one's own mistakes and inaccuracies and mainly from the experiences of older and more experienced colleagues.

8. Manners. Courtesy, honesty and thinking over stimuli from the environment are key abilities while dealing with participants of the game before, during and after the game, even of the official participates only as a spectator.

9. Teamwork. Teamwork depends on thorough pre-game meeting and practical application of agreed procedures during games. Effective communication and support among officials is necessary at each stage of the game.

10. Composure. It is necessary to follow the same pace and philosophy of decision making during the whole game. It is also necessary to be fair while dealing with both opponent teams and show sense for happens on the court and off it.

Šmíd a Horička (2013) also specify basic requirements on officials as a premises of their good performance in the match:
a) perfect official performance
b) knowledge of human nature
c) expression
d) tact
e) courtesy
g) loyalty
j) persuading players
h) objectivity
$\mathrm{m})$ friendly attitude
k) guardian of the rules
f) quick decision making
p) fair, hard game within rules
n) team captain use
i) dealing with coaches
I) foresight
r) signalling
o) courage
s) officials' dress-code

\section{MATERIAL AND METHODS}

The aim of the theoretical part of this paper was essential characteristic of function of a basketball official, its development and specification of requirements for managing of this function based on analysis of literature. The aim of the research was to determine mutual ratio of inputs in games from individual refereeing positions, to compare and statistically evaluate changes in in frequency of those inputs in three sequent MNBL seasons in the Czech Republic. A part of the research was also to define most common mistakes in a position of basketball official, followed by recommendations for practise. Because it was due to collecting data - observation of the highest male basketball competition games, we assume that it was also an analysis of performance of the best basketball officials in the Czech Republic. 
The research took place in 2011-2014 when we collected and then evaluated data from 15 basketball games in each given season by direct observation method. We observed 45 basketball games in total and individual data was recorded during each game into prepared forms and then verified by video if it was necessary to specify or check any data. The games were chosen by random selection on condition that each of the 12 teams attending the competition was monitored at least once.

Due to the nature of the metric obtained data (nominal and ordinal scale), the unknown distribution in the population and small research group, a nonparametric statistical analysis was conducted: chi-square for determining different absolute frequencies, Kolmogorov-Smirnov test to determine super maximum difference relative frequencies and Lord's test for determining the difference of the average values with respect to their range.

\section{RESULTS}

Following are processed data from the individual seasons of the basketball competition, the share of officials on the frequency of inputs into matches and total of errors. For each table there is a summary evaluation enclosure.

Table 1. Fouls / positions in season 2011-2012

\begin{tabular}{ccccc}
\hline Game & Lead & Center & Trail & $\Sigma$ \\
\hline 1 & 22 & 15 & 7 & 44 \\
2 & 25 & 16 & 12 & 53 \\
3 & 25 & 16 & 9 & 50 \\
4 & 25 & 11 & 6 & 42 \\
5 & 20 & 16 & 3 & 39 \\
6 & 24 & 10 & 10 & 44 \\
7 & 21 & 7 & 11 & 39 \\
8 & 23 & 13 & 10 & 46 \\
9 & 13 & 11 & 14 & 38 \\
10 & 20 & 13 & 3 & 36 \\
11 & 23 & 16 & 7 & 46 \\
12 & 20 & 7 & 9 & 36 \\
13 & 23 & 9 & 9 & 41 \\
14 & 28 & 10 & 9 & 47 \\
15 & 21 & 9 & 8 & 38 \\
\hline & $\times 22,2$ & $\times 11,9$ & $\times 8,5$ & $\times 42,6$ \\
\cline { 2 - 4 } & & & &
\end{tabular}

The average frequency of personal fouls in a game in 2011-2012 has been determined to 42.6 fouls / game, when variation range was from 36 to 53 of personal fouls in one game. The highest level of involvement in a game has been found on $L$ position officials ( 22.2 fouls / game), lower on the $C$ position (11.9 fouls / game) and T position officials were the least active ones ( 8.5 fouls / game). 
Table 2. Fouls / positions in season 2012-2013

\begin{tabular}{ccccc}
\hline Game & Lead & Center & Trail & $\Sigma$ \\
\hline 1 & 24 & 14 & 8 & 46 \\
2 & 17 & 21 & 11 & 49 \\
3 & 19 & 18 & 11 & 48 \\
4 & 19 & 19 & 6 & 44 \\
5 & 19 & 17 & 9 & 45 \\
6 & 24 & 11 & 4 & 39 \\
7 & 22 & 16 & 3 & 41 \\
8 & 15 & 12 & 11 & 38 \\
9 & 16 & 15 & 6 & 37 \\
10 & 12 & 13 & 8 & 33 \\
11 & 16 & 11 & 7 & 34 \\
12 & 21 & 18 & 8 & 47 \\
13 & 12 & 15 & 5 & 32 \\
14 & 13 & 15 & 7 & 35 \\
15 & 16 & 16 & 11 & 43 \\
\hline & $X 17,7$ & $X 15,4$ & $X 7,7$ & $\times 40,7$ \\
\cline { 2 - 4 } & & & &
\end{tabular}

The average frequency of personal fouls in a game in 2012-2013 has been determined to 40.7 fouls I game, when variation range was from 32 to 49 of personal fouls in one game. The highest level of involvement in a game has been found on $L$ position officials ( 17.7 fouls / game), lower on the $C$ position (15.4 fouls / game) and T position officials were the least active ones ( 7.7 fouls / game).

\begin{tabular}{|c|c|c|c|c|}
\hline Game & Lead & Center & Trail & $\sum$ \\
\hline 1 & 18 & 12 & 12 & 42 \\
\hline 2 & 27 & 11 & 11 & 49 \\
\hline 3 & 16 & 18 & 9 & 43 \\
\hline 4 & 13 & 22 & 8 & 43 \\
\hline 5 & 24 & 11 & 11 & 46 \\
\hline 6 & 22 & 12 & 9 & 43 \\
\hline 7 & 20 & 20 & 9 & 49 \\
\hline 8 & 15 & 12 & 10 & 37 \\
\hline 9 & 16 & 8 & 10 & 34 \\
\hline 10 & 25 & 9 & 13 & 47 \\
\hline 11 & 17 & 13 & 9 & 39 \\
\hline 12 & 18 & 12 & 12 & 42 \\
\hline 13 & 12 & 18 & 6 & 36 \\
\hline 14 & 14 & 11 & 15 & 40 \\
\hline \multirow[t]{2}{*}{15} & 24 & 19 & 13 & 56 \\
\hline & X 18.7 & $\times 13.9$ & $\times 10.5$ & X 43.1 \\
\hline
\end{tabular}


The average frequency of personal fouls in a game in 2013-2014 has been determined to 43.1 fouls / game, when variation range was from 34 to 56 of personal fouls in one game. The highest level of involvement in a game has been found on $L$ position officials (18.7 fouls / game), lower on the $C$ position (13.9 fouls / game) and T position officials were the least active ones (10.5 fouls / game).

Table 4. Comparison of results from 2011-2014

\begin{tabular}{ccccc}
\hline Season & Lead & Center & Trail & $\Sigma$ \\
\hline $2011-0112$ & 22.2 & 11.9 & 8.5 & 42.6 \\
$2012-2013$ & 17.7 & 15.4 & 7.7 & 40.7 \\
$2013-2014$ & 18.7 & 13.9 & 10.5 & 43.1 \\
\hline
\end{tabular}

The highest average of decisions in all observed seasons has been always found at officials on $L$ position, the frequency of their inputs into games was $17.7-22.2$ / match. The second most active position were officials on $\mathrm{C}$ position, the frequency of their inputs into games was $11.9-15.4$ / game. The least active ones were $T$ position officials, the frequency of their inputs into games was $7.7-10.5$ / game. In total of personal fouls blew by a whistle per game we found minimal differences among all three observed seasons. The range of personal fouls was $40.7-43.1$.

Table 5. Statistical analysis of the frequency of interventions referees in the game

\begin{tabular}{|c|c|c|c|c|c|c|}
\hline Season & Chi-square & Tabulated value & Hypothesis & Lambda & Tabulated value & Hypothesis \\
\hline $2011-2012$ & 107 & $\begin{array}{c}p 0.05 \\
5.99 \\
P 0.01 \\
9.21\end{array}$ & $\mathrm{H} / \mathrm{a}$ & 4.731 & $p 0.000$ & $\begin{array}{c}\mathrm{H} / \mathrm{a} \\
\mathrm{L} \text { position }\end{array}$ \\
\hline 2012-2013 & 60.3 & $\begin{array}{c}p 0.05 \\
5.99 \\
P 0.01 \\
9.21\end{array}$ & $\mathrm{H} / \mathrm{a}$ & 3.590 & $p 0.000$ & $\begin{array}{c}\mathrm{H} / \mathrm{a} \\
\text { T position }\end{array}$ \\
\hline 2013-2014 & 35.4 & $\begin{array}{c}p 0.05 \\
5.99 \\
P 0.01 \\
9.21\end{array}$ & $\mathrm{H} / \mathrm{a}$ & 2.474 & $p 0.000$ & $\begin{array}{c}\mathrm{H} / \mathrm{a} \\
\mathrm{L} \text { position }\end{array}$ \\
\hline
\end{tabular}

In years 2011-2012, 2012-2013, 2013-2014 we found a highly statistically significant difference according to the criteria of the frequency of the referees' decisions in relation to their individual positions $(L, C, T)$. From the given frequency formed super maximum difference in all three seasons frequency interference into the game the referee in the position L. Frequency of interventions into play at the two remaining positions did not differ significantly. 
Table 6. Statistical analysis central tendency and range of interventions referees in the game

\begin{tabular}{|c|c|c|c|c|}
\hline & Lord's test & Tabulated value & Hypothesis & Statistical significance of the difference \\
\hline \multicolumn{5}{|l|}{$2011-2012$} \\
\hline Position L/C & 0.429 & $\begin{array}{l}\text { p } 0.05 \\
0.108 \\
\text { p } 0.01 \\
0.145\end{array}$ & $\mathrm{Ha}$ & L position \\
\hline Position L/T & 0.527 & $\begin{array}{l}\text { p } 0.05 \\
0.108 \\
\text { p } 0.01 \\
0.145\end{array}$ & $\mathrm{Ha}$ & L position \\
\hline Position C/T & 0.17 & $\begin{array}{l}\text { p } 0.05 \\
0.108 \\
\text { p } 0.01 \\
0.145\end{array}$ & $\mathrm{Ha}$ & C position \\
\hline \multicolumn{5}{|l|}{$2012-2013$} \\
\hline Position L/C & 0.105 & $\begin{array}{l}\text { p } 0.05 \\
0.108 \\
\text { p } 0.01 \\
0.145\end{array}$ & HO & $L=C$ position \\
\hline Position L/T & 0.5 & $\begin{array}{l}\text { p } 0.05 \\
0.108 \\
\text { p } 0.01 \\
0.145\end{array}$ & $\mathrm{Ha}$ & L position \\
\hline Position C/T & 0.428 & $\begin{array}{l}\text { p } 0.05 \\
0.108 \\
\text { p } 0.01 \\
0.145\end{array}$ & $\mathrm{Ha}$ & C position \\
\hline \multicolumn{5}{|l|}{ 2013-2014 } \\
\hline Position L/C & 0.166 & $\begin{array}{l}p 0.05 \\
0.108 \\
p 0.01 \\
0.145\end{array}$ & $\mathrm{Ha}$ & L position \\
\hline Position L/T & 0.342 & $\begin{array}{l}\text { p } 0.05 \\
0.108 \\
\text { p } 0.01 \\
0.145\end{array}$ & $\mathrm{Ha}$ & L position \\
\hline Position $\mathrm{C} / \mathrm{T}$ & 0.148 & $\begin{array}{l}p 0.05 \\
0.108 \\
p 0.01 \\
0.145\end{array}$ & $\mathrm{Ha}$ & C position \\
\hline
\end{tabular}


When evaluating the average number of referees decisions in the game in relation to their positions, we found statistically significant difference between all positions in all three seasons with the sole exception of positions between the L / C in the season 2012-2013.

\section{DISCUSSION}

Probably because of only 10 years of three officials system in basketball games in the Czech Republic we have not found any literature dealing with the theme of this paper. We presume that some of the limiting factors of this state are mostly time and economy demands of the research when personal presence of the observer at each match with collection of data is irreplaceable. From the results of observations of individual positions it results that $L$ position is dominant to $C$ and $T$ position. In season 2011-2012, the $L$ official participated on the games by higher percentage of decisions comparing to percentage of both his $(\mathrm{L}$ $=52.1 \%, \mathrm{C}=27.9 \%, \mathrm{~T}=20 \%$ ). At this time, the pressure of FIBA on higher activity on $\mathrm{C}$ position and got much stronger in order to divide the ration of inputs into games and to deal with some situation from the $\mathrm{C}$ position instead of the $L$ position. In season 2012-2013, there was significant increase of inputs into games on $C$ position ( $9.9 \%$ more, compared to previous season), significant reduction of decisions on $L$ position and minimal change on $\mathrm{T}$ position. The total ratio of inputs was $\mathrm{L}=43.5 \%, \mathrm{C}=37.8 \%$ a $\mathrm{T}=18.9 \%$, which is considered to be essential change of the share of decision making compared to previous season in advance of the benefit of the team performance (the total of shares in positions $\mathrm{C}$ and $\mathrm{T}$ exceeded activity of $L$ position for $13.2 \%)$. In the last observed season we determined the average of inputs into games as following: $L=43.4 \%, C=32.3 \%$ a $T=24.4 \%$. The data was surprising, because the share of $L$ position decisions stayed stabilized and the activity of $C$ position was lessen for 5.5 . \%, in advantage of $T$ position. These inputs reflect the trend of mechanic of decision making instructed by FIBA, when the primal aim is to teach the officials to enter a game from $C$ position - in cooperation with both other officials and on the condition of following the authorities of all three positions, of course. In the first observed season this trend had brought problems with acceptance from the part of players, coaches and spectators, but after two finished seasons with this system, these decisions are taken in much better and we are convinced about the benefits of this trend for further development of basketball.

\section{CONCLUSIONS}

The conclusions of our research are presented at various points in the form of presentation of the most fundamental mistakes done while supervising the games and recommendations for practice:

Mistakes = unnecessary number of double / triple calls especially on positions of $T / C$ and $L / C$, not to enter the game unnecessarily (cheap calls), to follow the range of one's authority and always clearly see personal foul or violation / not to use fantasy calls, cross court calls, guess calls, not to stay near ending line while on the $L$ position, to be able to distinguish personal foul/ tactical and unsportsmanlike fouls.

Recommendations = to be more active at the $\mathrm{C}$ position during a game, to control hand checking more I especially with players under the baskets ("clean game" is the essential idea for the FIBA for decision making during a game), to apply greater control for game situations off the ball, to concentrate on the initiation of movement of a player with the ball held / travelling violation, to check the behaviour of players, coaches and benches of teams more. 
A token of stability of criteria in decision making in basketball is considered to be the minimum variation range of personal fouls during all observed seasons, which has been determined to be from 40.7 to 43.1 fouls per game.

We consider the transferring of some of the decision making responsibilities to $L$ position and its higher activity during a match to be a significant contribution to decision making in basketball games.

\section{REFERENCES}

1. Brazauskas, R. (2008). On the Court. Wroclaw: Camp for Potential Referees (unpublished).

2. Dobrý, L. \& Velenský, E. (1980) Košíková: teorie a didaktika. Praha: SPN.

3. Hruša, P. (2007). Závislost osobních chyb v basketbalovém utkání na prostoru a odehraném času. In Zborník vedeckých prác. Bratislava: Univerzita Komenského.

4. Jaffe, Y.R. (2008). Advantage disadvantage. Charleston: Vega.

5. Janáč, L. (1993). Mechanika a technika rozhodovania. Bánská Bystrica: Sportcentrum Iventa.

6. Priperkov, G. (2006). Physical Preparation of Basketball Referees before and During the Season. Gran Canaria: Camp for Young Referees (unpublished).

7. Pumr, M. et al (1987). Basketball pro rozhodčí všech tříd. Praha: Olympia.

8. Richardson, A. (2007). What I like in a Good Referee. Mildfield: Nationwide Basketball Referees' Camp (unpublished).

9. Robinson L.C. (2000). Training Basketball Officials. Bristol: Wyndham Hall Press.

10. Slepička, P. (1982). Sociální interakce ve sportovní činnosti. Praha: Univerzita Karlova.

11. Svoboda, B. \& Vaněk, M. (1986). Psychologie sportovních her. Praha: Olympia.

12. Šafařík, V. \& Stibitz, F. (1978). Rozhodování ve sportovních hrách. Praha: SPN.

13. Šmíd, P. (2000). Vliv fyzického zatížení na techniku a mechaniku rozhodování v basketbalu. Disertační práce. Brno: Masarykova Univerzita.

14. Šmíd, P. \& Horička, P. (2013). Vývojové trendy v rozhodování basketbalu žen. In Optimální pưsobení tělesné zátěže 2013 (pp. 279-286). Hradec Králové: Pedagogická fakulta UHK.

15. Trnovský, I. et al. (1992). Teória a didaktika športovej specializácie: basketball. Bratislava: Univerzita Komenského.

16. Vyklický, R. (2001). Osobnost rozhodčiho. Retrieved from http://vyklicky.tripod.com/clankycz_top.htm 